\section{Stratejik Plan, Bireysel Performans Değerlendirmesi İlişkisine Dair Algı Hakkında Bir Araştırma ${ }^{1}$}

A Survey About Perception Related to Strategic Plan and

Individual Performance Appraisal Relation

\section{Serdar ERBAŞ ${ }^{2}$}

Strategic Public Management Journal Volume 7, Issue 13, pp. 10-34

May 2021

DOI: $10.25069 /$ spmj.857326

Research Article/Araştırma Makalesi

Received: 09.01.2021

Accepted: 07.05.2021

(C) The Author(s) 2021

For reprints and permissions:

http://dergipark.gov.tr/spmj

\title{
$\ddot{O}_{z}$
}

Kamu kurumlarının ve genel olarak Devletin başarılı olabilmesi, kalkınma planı, orta vadeli program gibi üst politika belgelerinin kurumların stratejik plan ve eylem planlarına aktarlması ve bu planları etkin olarak uygulanabilmesine bağlıdır. Kamu kurumlarının stratejik planlarında ve daha üst politika belgelerinde belirlenen amaç ve hedeflerine ulaşabilmeleri, başarll olabilmeleri de kurumsal performansin ve kamu görevlilerinin bireysel performanslarının belli bir düzeyde olmasını gerektirmektedir. Bu çalışmada, stratejik plan uygulaması ile kamu çalışanlarının bireysel performanslarının değerlendirilmesini sağlayacak bireysel performans değerlendirme ve yönetim sistemi kurulmasına dair Sağlık Bakanlığı çalışanlarının algısının anlaşılması amaçlanmış, anket yöntemi ile literatür araştırması yöntemleri kullanılmıştır. Kamu kurumlarında stratejik planların uygulanabilmesi ile kamu görevlilerinin bireysel performansları ve performans değerlendirmesi arasında önemli bir ilişki olduğu söylenebilir. Anket araştırması sonuçlarına göre, stratejik plan hakkında bilgi sahibi olan Să̆llk Bakanlı̆̆ çalışanlarının, bireysel performans de ğerlendirmesi ile ilgili daha pozitif bir yaklaşım gösterdikleri sonucuna ulaşılmıştır. Katılımcı yöntemlerle profesyonelce stratejik planlar hazırlanması ve bu planların nitelikli kamu görevlileri ile uygulanması, nitelikli çalışanların performanslarının yüksek tutulabilmesi için bireysel performans değerlendirmesi yapılmasının, kamu yönetiminin etkinliğini artırmada, küreselleşen, rekabet odaklı dünyada ülkemizin rekabet gücünün artırllmasında etkili araçlar olduğu sonucuna ulaşılmıştır.

Anahtar Kelimeler: Sağlık Bakanlı̆̆l, Stratejik Plan, Bireysel Performans Yönetimi, Bireysel Performans Değerlendirmesi.

\footnotetext{
Abstract

Achievement of governmental organisations and state in general depends on high level policy documents like development plans and medium run programmes to be transmitted to organisations' strategic plans and action

${ }^{1} \mathrm{Bu}$ çalışmada, Dr. M. Serdar ERBAŞ tarafindan hazırlanan YÖK Tez Veri Tabanında 587348 no ile kayıtlı "Kamu Kurumlarında Bireysel Performans Yönetimi ve Değerlendirme Sistemi: Kamu Çalışanları ile Yapılan Bir Araştırma" konulu Doktora Tezinden yararlanılmıştır. Anket araştırması için Üniversiteden 27/08/2018 tarihli ve 2008/11 sayılı Etik Kurulu Kararı alınmış, Sağlık Bakanlığından 15/09/2018 tarihli araştırma izni alınmıştır.

${ }^{2}$ Başmüfettiş, Sağlık Bakanlığı Teftiş Kurulu Başkanlı̆̆ı, mserdar.erbas@saglik.gov.tr, ORCID ID: 0000-0002-28650166
} 
plans and their effective implementation. Governmental organisations' and public officials' performance is needed to be at a certain level to be successful and to reach aims and objectives determined in strategic plans and high level policy documents. In this article, it was aimed to understand perceptions of Ministry of Health public officers about strategic plan implementation and formation of an individual performance appraisal and management system which will provide public officials' performance to be assessed and questionnaire survey method and literatüre search method was used. It can be said that there is a strong relation between implementation of strategic plans and public officials' performance level and performance appraisal. It was concluded from questionnaire survey that public officers in ministry of health who have information about strategic plan have more positive approach towards individual performance appraisal. It was concluded that preparing strategic plans with participative methods and implementing them with highly skilled public officials, appraising skilled public officials' performance to keep up their performance level high, are efficient instruments to increase efficiency of public administration and state's competition power in today's competion based world.

Key Words: Ministry of Health, Strategic Plan, Individual Performance Management, Individual Performance Appraisal.

\section{GíRiş}

Kamu kurum ve kuruluşlarının karar alma ve uygulama süreçlerinde, kalkınma planı ve orta vadeli program gibi üst politika belgeleri de dikkate alınarak stratejik plan hazırlanması ve uygulanması başarı için çok önemlidir. Kamu kurum ve kuruluşlarının kamu politikalarını oluştururken ve karar alırken stratejik planlamanın sağladığı sistem, yaklaşım ve yöntemden faydalanmaları; amaçlara zamanında ve gerektiği şekilde ulaşmak için gereklidir. Kamu ya da özel sektör kuruluşlarında amaç ve hedeflerinin belirlenmesi ile bu amaç ve hedeflere ulaşmak için gerekli proje ve planlarının ve bütçelerinin, başarı ve performans göstergelerinin belirlenmesi ve kurumun amaçlara ulaşmadaki başarısının ölçümü ve izlenmesi süreçleri önem taşımaktadır.

Değişmekte zorlanan bürokratik kamu yönetimi yerine daha esnek ve yüksek performans odaklı bir kamu yönetiminin nasıl oluşturulabileceği konusu önemli bir gündem maddesidir. Kamu görevlilerinin bireysel performanslarının değerlendirilmesi konusu bu noktada öne çıkmaktadır. Zira kamu yönetimi sisteminin temelini kamu kurumları ve kamu çalışanları oluşturur. Kamu görevlilerinin performansları yeterli düzeyde oldukça kamu kurumlarının ve bir bütün olarak kamu yönetiminin amaçlarına zamanında ulaşması yani başarılı olabilmesi mümkün olacaktır.

Kamu kurumlarında da stratejik planlarında belirlenen amaç ve hedeflere ulaşmada ve verilen görevlerin yerine getirilmesinde kamu kurumlarının ve çalışanlarının kurumsal ve bireysel performansın değerlendirilmesi ve yönetilmesi gün geçtikçe önem kazanmaktadır. Zira kalkınma planları ve orta vadeli programlar ile çizilen genel çerçeve kamu kurumlarının stratejik planları ile hayata geçirilmekte ve tüm ülkenin amaç ve hedeflerine ulaşması için kamu kurum ve kuruluşları kendi üzerlerine düşen görevleri yerine getirmek için stratejik planlarını hazırlayıp uygulamaktadırlar. Ülkenin bir bütün olarak amaç ve hedeflerine ulaşabilmesi kamu kurumları ve çalışanlarının bu görev ve amaçları yerine getirebilecek kapasite ve performansa sahip olmaları ile mümkün olabilecektir. Türkiye'de Sayıştay tarafından kamu kurumlarının stratejik planları, faaliyet raporları ve performans programları esas alınarak kurumsal performans değerlendirmeleri yapılmaktadır. 657 
sayılı Yasada yapılan değişiklik ile memurlar için sicil raporları uygulamasının kaldırılması ile kamu görevlilerinin bireysel performans ve yetkinliklerinin değerlendirilmesine dair mevcut tek genel uygulama ortadan kaldırılmış olup kamu görevlilerine yönelik bireysel performans sistemi kurulması ve performans değerlendirmesi yapılması ihtiyacı ortaya çıkmıştır. Yine 1 sayılı Cumhurbaşkanlığ 1 Kararnamesinin "Performans değerlendirmesi" başlıklı 374. Maddesinde, "Bakanlık ve bağlı kuruluşlarında; bakan; bakan yardımcısının, bakan yardımcıları, kurum başkanları, müstakil birim amirleri ve il müdürlerinin, başkan ve genel müdür; başkan yardımcısl, genel müdür yardımcısl, genel sekreter ve halk sağlı̆̆ı müdürünün, diğer yöneticiler; hiyerarşik olarak kendilerine bağlı bir alt kademedeki personelin performanslarını, verilen görevlere ve belirlenen hedeflere göre değerlendirir. Stratejik planlar, performans programları ve faaliyet raporları 5018 sayıl Kanuna uygun olarak oluşturulur ve ilgili kurumlara iletilir.” denilerek kamu sağlik kuruluşlarında bireysel performans değerlendirmesi yasa hükmünde yönetsel düzenlemeye konu olmuştur (1 sayılı Cumhurbaşkanlığı Kararnamesi, 372 ve 374. Madde).

Türkiye Büyük Millet Meclisi (TBMM) ve kamu iktisadi teşebbüslerinde (KİT) bazı örnek bireysel performans değerlendirmesi uygulamaları yapılmıştır. Yine Sağlık Bakanlığının hastanelerde çalışan kamu çalışanlarına yönelik ücretlendirme ile bağlantılı performans değerlendirme/ölçüm sistemi gibi bazı uygulamalar hayata geçirilmiş ise de bütün kamu kesimini kapsayan bir bireysel performans değerlendirme sistemi henüz uygulamaya konmamıştır. Bireysel performans değerlendirmesi yapılmaksızın sadece kurum düzeyinde performans değerlendirilmesi yapılarak genel performans çıktılarına bakılması, sonuçlara katkısı olmayan, hatta performansı düşüren çalışanların da ödüllendirilmesine neden olabilir. Bu durum, kurumun performansına katkısı az olan ya da hiç katkısı olmayan çalışana göre daha çok çalışan özverili personelin iş tatminini, motivasyonunu, kuruma bağlılığını ve iş performansını düşürebilir. Bu noktada çalışanların bireysel performanslarının yüksek olmasının kurum performansını olumlu etkileyeceği, kurumun amaç ve hedeflerine zamanında ve gerektiği şekilde ulaşmasına ve stratejik planların etkin şekilde uygulanmasına yardım edeceği muhakkaktır. Bu nedenle kamu kurumlarında da bireysel performans yönetim sistemi ve değerlendirmesinin hak ettiği yeri alabilmesi tüm ülkenin ve kamu yönetiminin gelişimi ve geleceği açısından hayati önemdedir.

Bu makalede, stratejik plan uygulaması ile kamu çalışanlarının bireysel performanslarının değerlendirilmesini sağlayacak bireysel performans değerlendirme ve yönetim sistemi kurulmasına dair Sağlık Bakanlığı çalışanlarının algısının anlaşılması amaçlanmış, anket yöntemi ile literatür araştırması yöntemleri kullanılmıştır. Stratejik planlama ve bireysel performans değerlendirmesi kavramsal olarak değerlendirilmiş, yasal ve yönetsel düzenlemeler ele alınmış ve araştırma sonuçları gösterilmiştir.

\section{TÜRK KAMU YÖNETIMINDE STRATEJİK PLANLAMA}

Ülkemizde kamu yönetiminde stratejik planlama uygulaması açısından, 5018 sayılı Yasa ile başlamıştır. Bu kapsamda stratejik plan kavramı, strateji geliştirme birimleri, faaliyet raporu ve performans programı hazırlanması ile düzenlemeler önem taşımaktadır.

\subsection{Stratejik Plan Kavramı ve Stratejik Planlama}

Strateji kelimesinin etimolojik kökeni, Eski Yunancaya dayanmaktadır. Strateji, eski Yunanca "stratos" (ordu) ve "ago" (yönetmek, yön vermek) kelimelerinin birleştirilmesiyle oluşturulmuştur. Kelimenin etimolojik yönden Latince, "stratum" kelimesinden türediğini ifade edenler de vardır. Latincede "stratum"; "yol, çizgi, 
nehir yatağı" anlamlarına gelmektedir. Strateji kelimesinin sözlük anlamı ise, bir amaca ulaşmak için faaliyet ve davranışlarda yeknesaklığg sağlama ve düzenleme, olarak ifade edilmektedir (Aktan, 2006:1).

Stratejik yönetim süreci, beş aşamadan oluşmaktadır. Bunlar, planlama, organize etme, yürütme, eşgüdüm sağlama ve kontrol unsurlarıdır. Bu anlamda stratejik planlama, stratejik yönetimin önemli bir unsurudur. Stratejik planlama süreci ise, vizyon, misyon ve etik değerlerin belirlenmesi, kurum amaçlarının belirlenmesi, strateji oluşturma süreci ve uygulama sonuçlarının izlenmesi ile değerlendirilmesi aşamalarından oluşmaktadır. Misyon ifadesi, kurumun varlık nedenini, vizyon, geleceğe bakışı gösterirken amaçlara ulaşılması için gerekli ilkeler ve ortak değerler de stratejik planda bulunur. Misyon, kurum açısından, "Niçin varız" sorusunun cevabıdır (Akgemci ve Güleş, 2010: 10-13).

Stratejik yönetim, öncelikle üst yönetimin sorumluluk yükünü azaltır. Üst yöneticiler karş1laşılan sorunları aşmak ve kime, hangi mal ve hizmetlerin sunulacağına dair stratejik kararlar almak durumundadırlar. Bu noktada stratejik plan yönetsel kararlara esas olması açısından önem taşımaktadır.

\subsection{Yasal ve Yönetsel Düzenlemeler}

Türk kamu yönetiminde 5018 sayılı Kamu Mali Yönetimi ve Kontrol Kanunu ile "Stratejik Planlama" ve bununla bağlantılı olarak faaliyet raporu, performans programı, kurumsal mali durum ve beklentiler raporu hazırlanması uygulaması başlamıştır. Stratejik planlar, kamu kurum ve kuruluşunun amaç ve hedefleri ile bunlara ulaşmak için gerekli faaliyet, proje ve planları, performans göstergelerini, kilit başarı göstergelerini içermekte, hem kurumsal hem de bireysel performansın ölçümüne ilişkin hedef ve göstergeleri içermektedir.

Türkiye'de kamu yönetimi ve özellikle mali yönetiminde yeniden yapılanma amacıyla, 5018 sayılı Kamu Mali Yönetim ve Kontrol Kanunu yürürlüğe konmuştur. Dünyada yaygınlaşan kalite yönetimi, performans yönetimi, stratejik yönetim, vizyon yönetimi gibi uygulamalar ülkemizde de yaygınlaşmış bunda Avrupa Birliğinin (AB) de etkisi olmuştur (Özer, 2008: 513).

5018 sayılı Kamu Mali Yönetim ve Kontrol Kanununun, "Stratejik Planlama ve Performans Esaslı Bütçeleme" başl1klı 9. Maddesinde yer alan "Kamu idareleri; kalkınma planları, programlar, ilgili mevzuat ve benimsedikleri temel ilkeler çerçevesinde geleceğe ilişkin misyon ve vizyonlarını oluşturmak, stratejik amaçlar ve ölçülebilir hedefler saptamak, performanslarını önceden belirlenmiş olan göstergeler doğrultusunda ölçmek ve bu sürecin izleme ve değerlendirmesini yapmak amacıyla katılımcı yöntemlerle stratejik plan hazırlarlar... Kamu idareleri, yürütecekleri faaliyet ve projeler ile bunların kaynak ihtiyacını, performans hedef ve göstergelerini içeren performans programı hazırlar. Kamu idareleri bütçelerini, stratejik planlarında yer alan misyon, vizyon, stratejik amaç ve hedeflerle uyumlu ve performans esasına dayalı olarak hazırlarlar." hükmü ile stratejik plan, performans programı hazırlanması görev ve sorumluluğu yönetime verilmiştir.

$\mathrm{Bu}$ şekilde, 5018 sayılı Kanun ile kamu idarelerine kalkınma planları, programlar, ilgili mevzuat ve benimsedikleri temel ilkeler çerçevesinde geleceğe ilişkin misyon ve vizyonlarını oluşturmak, stratejik amaçlar ve ölçülebilir hedefler saptamak, performanslarını önceden belirlenmiş olan göstergeler doğrultusunda ölçmek ve uygulamanın izleme ve değerlendirmesini yapmak amacıyla katılımcı yöntemlerle stratejik plan hazırlanması ve uygulanması başlamıştır. Kanunda, stratejik planlama performans esaslı bütçeleme ile bir arada ele alınmıştır. Kanuna göre, kamu kurumları bütçelerini stratejik planlarına, stratejik planlarında yer alan 
misyon, vizyon stratejik amaç ve hedeflerle uyumlu ve performans esasına dayalı olarak hazırlayacaklardır. Performans göstergeleri kamu kurumlarının bütçelerinde yer alacak ve performans denetimleri bu göstergeler çerçevesinde gerçekleştirilecektir.

"Kamu İdarelerinde Stratejik Planlamaya İlişkin Usul ve Esaslar Hakkında Yönetmelik" 26/5/2006 tarihli ve 26179 sayılı Resmî Gazete' de yayımlanarak yürürlüğe konmuş sonrasında, 26/02/2018 tarihli ve 30344 sayılı Resmi Gazetede yayımlanan "Kamu İdarelerinde Stratejik Planlamaya İlişkin Usul ve Esaslar Hakkında Yönetmelik" yürürlüğe girmiştir. 5018 sayılı Kanunda, stratejik plan hazırlamakla yükümlü olacak kamu idarelerinin ve stratejik planlama sürecine ilişkin takvimin tespitine, stratejik planların kalkınma planı ve programlarla ilişkilendirilmesine yönelik usul ve esasların belirlenmesine mülga Devlet Planlama Teşkilatı Müsteşarlığ yetkili kılınmıştır. Bu kapsamda, kamu idarelerine stratejik planlama sürecinde yol göstermek üzere mülga Devlet Planlama Teşkilatı tarafından "Kamu İdareleri İçin Stratejik Planlama Kılavuzu" hazırlanmıştır. Halen 13 sayılı Cumhurbaşkanlığı Kararnamesi ile düzenlenen Cumhurbaşkanlığı Strateji ve Bütçe Başkanlığı bünyesinde bu işlemler yürütülmektedir.

\subsection{Strateji Geliştirme Birimleri (Mali Hizmetler Birimi)}

5018 sayılı Kanun ile kamu kurumlarının stratejik yönetim ve planlama faaliyetlerini organize etmek üzere “strateji geliştirme birimleri” oluşturulmuştur. 5436 sayılı Kanunla 5018 sayılı Kamu Mali Yönetimi ve Kontrol Kanununda önemli değişiklikler yapılarak, harcama öncesi ön mali kontrol yeniden düzenlenmiş ve mali hizmetler uzmanı kadroları oluşturulmuştur. 5018 sayılı Kanunun 60. Maddesinde mali hizmetler birimine verilen görevler ile diğer bazı görevleri yürütmek üzere 'strateji geliştirme birimleri” başkanlık, daire başkanlığı veya müdürlük şeklinde oluşturulmuştur.

2005 yılında kabul edilen 5436 sayılı Kanun ile 5018 sayılı Kanunun 60 incı maddesi değiştirilmiş ve Kamu idarelerinde aşağıda sayılan görevlerin malî hizmetler birimi tarafından yürütüleceği belirtilmiştir;

$\checkmark$ İdarenin stratejik plan ve performans programının hazırlanmasını koordine etmek ve sonuçlarının konsolide edilmesi çalışmalarını yürütmek.

$\checkmark \quad$ İzleyen iki yılın bütçe tahminlerini de içeren idare bütçesini, stratejik plan ve yıllık performans programına uygun olarak hazırlamak ve idare faaliyetlerinin bunlara uygunluğunu izlemek ve değerlendirmek.

$\checkmark$ Mevzuatı uyarınca belirlenecek bütçe ilke ve esasları çerçevesinde, ayrıntılı harcama programı hazırlamak ve hizmet gereksinimleri dikkate alınarak ödeneğin ilgili birimlere gönderilmesini sağlamak.

$\checkmark$ Bütçe kayıtlarını tutmak, bütçe uygulama sonuçlarına ilişkin verileri toplamak, değerlendirmek ve bütçe kesin hesabı ile malî istatistikleri hazırlamak.

$\checkmark$ İlgili mevzuatı çerçevesinde idare gelirlerini tahakkuk ettirmek, gelir ve alacaklarının takip ve tahsil işlemlerini yürütmek.

$\checkmark$ Genel bütçe kapsamı dışında kalan idarelerde muhasebe hizmetlerini yürütmek.

$\checkmark$ Harcama birimleri tarafindan hazırlanan birim faaliyet raporlarını da esas alarak idarenin faaliyet raporunu hazırlamak. 
$\checkmark$ İdarenin mülkiyetinde veya kullanımında bulunan taşınır ve taşınmazlara ilişkin icmal cetvellerini düzenlemek.

$\checkmark$ İdarenin yatırım programının hazırlanmasını koordine etmek, uygulama sonuçlarını izlemek ve yıllık yatırım değerlendirme raporunu hazırlamak.

$\checkmark$ İdarenin, diğer idareler nezdinde takibi gereken malî iş ve işlemlerini yürütmek ve sonuçlandırmak.

$\checkmark$ Malî kanunlarla ilgili diğer mevzuatın uygulanması konusunda üst yöneticiye ve harcama yetkililerine gerekli bilgileri sağlamak ve danışmanlık yapmak.

$\checkmark$ Ön malî kontrol faaliyetini yürütmek.

$\checkmark$ İç kontrol sisteminin kurulması, standartlarının uygulanması ve geliştirilmesi konularında çalışmalar yapmak.

$\checkmark$ Malî konularda üst yönetici tarafindan verilen diğer görevleri yapmak.

18/02/2006 tarihli ve 26084 sayılı Resmi Gazetede "Strateji Geliştirme Birimlerinin Çalışma Usul ve Esasları Hakkında Yönetmelik" yayımlanmış ve yürürlüğe girmiştir. Yönetmelik ile strateji geliştirme birimlerinin görevleri; "stratejik yönetim ve planlama" başlı̆̆ı altında; misyon belirleme, kurumsal ve bireysel hedefler oluşturma, veri analizi ve araştırma, geliştirme; "performans ve kalite ölçütleri geliştirme", "yönetim bilgi sistemi”, "malî hizmetler" başlıkları altında; bütçe ve performans programı, muhasebe, kesin hesap ve raporlama ve iç kontrol olarak sayılmıştır.

\subsection{Faaliyet Raporu ve Performans Programı}

Türk kamu mali yönetimi, AB mevzuatına uyum sürecinde mali saydamlık ve hesap verebilirlik kavramları ile tanışmış ve böylece kamuoyunun bilgilendirilmesi bir kural haline gelmiştir. 5018 sayılı Kanunun 41. Maddesi ile kamuoyunu ve yasama organını yürütmenin faaliyetleri hakkında bilgilendirmek amacıyla yönetsel hesap verebilirlik çerçevesinde, idarelere stratejik plan ve performans programı ile faaliyet raporu hazırlanması görev ve sorumluluğunu getirmiştir (Benli, 2011: 70-72).

Kamu Mali Yönetim ve Kontrol Kanununun 41. Maddesinde, “Üst yöneticiler ve bütçeyle ödenek tahsis edilen harcama yetkililerince, hesap verme sorumluluğu çerçevesinde, her yll faaliyet raporu hazırlanır. Üst yönetici, harcama yetkilileri tarafindan hazırlanan birim faaliyet raporlarını esas alarak, idaresinin faaliyet sonuçlarını gösteren idare faaliyet raporunu düzenleyerek kamuoyuna açılar. Merkezî yönetim kapsamındaki kamu idareleri ve sosyal güvenlik kurumları, idare faaliyet raporlarının birer örneğini Sayıştaya ve Maliye Bakanlığına gönderir." hükmü bulunmaktadır. Bu kapsamda, 17.03.2006 tarihli ve 26111 sayılı Resmi Gazetede “Kamu İdarelerince Hazırlanacak Faaliyet Raporları Hakkında Yönetmelik” yayımlanmıştır.

5018 sayılı Kamu Mali Yönetim ve Kontrol Kanununun, "Stratejik planlama ve performans esaslı bütçeleme" başl1kl1 9. Maddesinde bulunan "Kamu idareleri, yürütecekleri faaliyet ve projeler ile bunların kaynak ihtiyacını, performans hedef ve göstergelerini içeren performans programı hazırlar. ... Performans denetimleri bu göstergeler çerçevesinde gerçekleştirilir." hükmü ile hem stratejik plan, hem performans programı hazırlanması görev ve sorumluluğu yönetime verilmiştir. Bu kapsamda 05.07.2008 tarihli ve 26927 sayıl1 Resmi Gazetede yayımlanan "Kamu İdarelerince Hazırlanacak Performans Programları Hakkında Yönetmelik" yürürlüğe girmiştir. 


\section{TÜRK KAMU YÖNETIMINDE BİREYSEL PERFORMANS}

Bireysel performansa ilişkin temel kavramlar, kamu yönetiminde bireysel performans değerlendirmesini gerektiren sebepler ile zorlaştıran unsurlar birlikte değerlendirilmektedir.

\subsection{Temel Kavramlar}

Performans, çalışanın çalışmasının bir sonucu olarak çalışanın ya da ekibin, kurum ve birim amaçlarına nicelik ve nitelik olarak katkılarının toplamı olarak tanımlanabilmektedir. Başka bir ifadeyle performans, çalışanın işini ve görevlerini ne ölçüde başarıyla yaptı̆̆ını belirtmekte; çaba, beceri, görev algılamaları gibi etkenlerden etkilenmektedir (Akyol, 2011: 83). Bir başka tanıma göre performans, belirlenen standartlara göre, bir işin yerine getirilme seviyesi veya çalışanın davranış biçimidir. Aynı okuldan mezun olan, aynı yaşta aynı zamanda aynı mesleğe atanan kişilerden birisi üst kademelere doğru yükselebilirken bir diğeri yerinde kalabilmektedir. $\mathrm{Bu}$ farklılığın nedeni çoğunlukla kişinin performansıdır. Performans başarı ile eş anlamlıdır. Önceden belirlenmiş kişisel amaçlar olmadan başarılı olmak mümkün değildir (Bingöl, 2014: 367).

Bireysel Performans, kurumun amaçlarına ulaşabilmesi için çalışanın sahip olduğu ve kullandığı yetkinlikler olarak tanımlanabilmektedir. Bu yetkinlikler, sadece işe yönelik değil işe yönelik olmayan görevleri, davranışları da içermektedir. Doğrudan işe yönelik olmayan yetkinlikler arasında, takım çalışması, müşteri odaklılık, istekli ve coşkulu olma, yardımseverlik, kurum kültürünü sahiplenme ve bireysel disiplin say1labilir. Bireysel performansı oluşturan üç unsur ise aşağıdaki gibi sıralanabilir:

\section{$\checkmark$ Odaklanma \\ $\checkmark$ Yetkinlik \\ $\checkmark$ Adanma (Barutçugil, 2015: 46-47).}

Bireysel performans yönetimi, insan kaynakları yönetim sisteminin önemli bir aracıdır. Kurum çalışanlarının tümünü kapsar. Özetle çalışanların çalışma ve başarılarının yönetilip kontrol edilmesi olarak özetlenebilir (Göze, 2008: 35).

Bireysel performans değerlendirme, bir kurumda çalışanların belirlenen amaç ve hedeflere ne kadar etkili ve verimli bir şekilde ulaştıklarının ya da kendilerine verilen görevleri yerine getirmede başarı derecelerinin ölçülmesi ve değerlendirilmesi sürecidir. Performansın düzeyinin belirlenebilmesi için yürütülen faaliyetlerin değerlendirilmesi gerekir. Performans değerlendirme, bireysel performans değerlendirme ve kurumsal performans değerlendirme olarak ikiye ayrılabilir. Literatürde daha sık karşılaşılan bireysel performans değerlendirmedir (Turhan, 2009: 76).

Performans ölçümü, yeni kamu yönetiminin bileşenlerinden biri olup kamu kurumlarına girdi/çıtı oranı hakkında fikir ve başarılarını sınama imkanı vermektedir. Kamu politikalarının yapılış ve uygulama aşamalarında oldukça önemli bir boşluğu doldurma potansiyelini taşımaktadır. Temel mantık kamu yöneticilerinin vergi ödeyicilere yani halka hesap vermesi gerekliliğidir. Fazlaca entellektüel birikim gerektirmeyen rutin işlerde performansın ölçülmesi mümkündür. Burada özellikle nesnel performans ölçütleri ortaya koymak mümkündür. Bu noktada hangi performans değerlendirme yönteminin kullanıldığ 1 da önemlidir (Kutlu, 2012: 79-81). 
Kurumsal performans karnesi yaklaşımı, Robert Kaplan ve David Norton tarafından geliştirilmiştir. Kurumsal performans karnesi, geçmiş performansı yansıtan mali ölçümler ile mali olmayan ölçümleri birleştirmektedir. Kurumsal performans karnesinin ölçümleri ve amaçları, kurumun vizyonundan ve stratejisinden beslenmekte, kurumsal performansı dört boyutta incelemektedir. Bu boyutlar; mali boyut, müşteri boyutu, iç iş süreçleri boyutu ve öğrenme/gelişme boyutlarıdır. Sosyal içerikli kurumlarda kalite, müşteri ve sosyal sorumluluk gibi boyutların da kurumsal performans karnesine eklenmesi gerekmektedir (Korkmaz, 2011: 11, 71). Bu yöntem, misyon ve strateji arasında bir köprü vazifesi görmekte, kurumların hem somut hem soyut unsurlarını bütüncül olarak değerlendirerek stratejilerin belirlenmesi ve faaliyetlerin gerçekleştirilmesini amaçlamaktadır (Eroğlu, 2011: 195).

\subsection{Performans Değerlendirmesini Destekleyen Durumlar}

Günümüzde kamu hizmetinden beklentiler değişmiştir. Vatandaşlar artık daha hızlı ve kaliteli kamu hizmeti talep etmektedirler. Bu durum da özel sektörün sunduğu hizmet kalitesi ile kamu kurumlarının sunduğu hizmetin kalitesinin karşılaştırılması etkili olmaktadır (Göküş ve Karayıldırım, 2012:130). Bu durum Türk kamu yönetimi ve bürokrasisinin yeniden yapılanmasını etkilemektedir. Türk kamu yönetiminin temel sorunları, kurumsallaşma ve işleyişte sorunlar, aşırı bürokrasi, kaynakların kamu kurumlarına dağılımında misyon ve stratejik planların dikkate alınmaması, verimsizlik, vizyon eksikliği, vatandaşların kamu hizmetleriyle ilgili bilgilere erişememesi, sorumluluk ve koordinasyon eksikliği, iletişim yetersizliği, denetim sorunları, personel sisteminin etkin olmayışı olarak sayılmaktadır (Saran, 2004:121-141. Özellikle bilişim ve iletişim teknolojisindeki gelişmeler, e-devlet uygulamaları, geleneksel bürokratik kurumları da kaçınılmaz olarak etkilemektedir. Bürokratik yapılar daha vatandaş odaklı yapılara dönüşmektedir (Ergun, 2015: 366). Türk kamu yönetiminde yaşanan etkinlik ve verimlilik arayışı ile birlikte, kamu yönetiminde performans yönetimi ve değerlendirmesi, etkinlik ve verimliliği sağlamaya yönelik etkin bir araç olarak değerlendirilmektedir. Diğer taraftan, vatandaşların hızla benimsediği hizmet kullanıcısı yani müşteri rolü, kamu kurumlarını kamu hizmetini en kaliteli biçimde ve en hızlı şekilde sunma ve vatandaşı memnun etme yükümlülüğüne zorlamaktadır. Bu durum doğal olarak yeni düzenleme ve uygulamaların yapılmasını gerektirmektedir. Yapılan bazı araştırmalar vatandaşın, kurumsal etkinlikten çok kullanıcı memnuniyeti üzerinde odaklandığını göstermektedir (Yerli, 2006: 85-86).

Türkiye'de halen genel olarak uygulanmakta olan kıdeme dayalı ücret/maaşın, performans artırıcı etkisinin az olması sistemin doğasından kaynaklanmaktadır. Zira çalışanın başarısı ne olursa olsun aynı ücreti ya da maaşı alıyorsa motivasyon artıran güdüler zayıflamaktadır. Başarıyı temel alan ücretin motivasyonu artırma olasılığ daha yüksektir. Çalışanın kıdeminin artmasıyla birlikte maaşın da düzenli bir artış garantisi olduğunda çalışan performansını artırmak için yeterli gerekçe olmadığını düşünebilmektedir. Performansa göre mali imkan sağlanması halinde ise, bu durum motivasyonu artırıcı bir unsur olabilmektedir. Diğer yandan, çalışanlar arasında rekabetin ortaya çıkması nihai başarıyı artırıcı etki oluşturmaktadır (Kavuzlu, 2007: 93). Kamu yararı kapsamında mal ve hizmet üreten kurumlarda, sistemin iyi tasarlanmamış olması, kurumların meşruiyeti üzerinde tartışma oluşturabilir. Çünkü, yönetim bilimi açısından meşruiyet, yönetsel faaliyetlerin başarısının, yurttaş memnuniyetinin, kamu politikası karar ve uygulamalarının desteklendiğinin bir göstergesi olarak ifade edilmektedir (Y1lmazgil, 2012: 166).

$\mathrm{Bu}$ nedenle, kamu hizmetlerinden ve bu hizmeti sunan kamu kurumlarından vatandaşın memnun olmaması ya da kurumların başarılı olamaması, vatandaş nezdinde kamu kurumunun meşruiyetine zarar verebilmektedir. 
Kamu kurumlarının zarar etmeleri yöneticilerin görevden alınmaları için bir sebep olmayabildiğinden ve özel sektördeki gibi iflas durumu da söz konusu olmadığından, kamu kurumlarında özel sektörle karşılaştırıldığında verimlilik ve etkinlik oranı bazen daha düşük düzeyde kalabilmektedir. Ayrıca kamu hizmetlerinin bazı alanlarda tekel nedeniyle rekabetten uzak olması, piyasada tekel piyasasının olumsuzlarının yaşanmasına neden olabilmektedir (Özkaya, 2013: 34). Bunlar, kamu kurumlarının ve çalışanların bireysel performans değerlendirmesini gerektiren nedenlerdendir. Bütün bunlar bireysel performans değerlendirmesinin nasıl yapılabileceği tartışmasını beraberinde getirmektedir.

Bu noktada, ülkemizde 5018 sayılı Kamu Mali Yönetimi ve Kontrol Kanunu ile stratejik plan, performans programı, performans denetimi gibi uygulamaların başlaması ve yaygınlaşması kamu kurumlarının verimlilik ve etkinlik açısından özel sektör kuruluşları ile rekabet edebilir hale gelmelerinde önemli bir rol oynamaktadır.

Kamu yönetimin etkin ve verimli çalışması ve kaliteli hizmet sunması, tüm ülke ekonomisini, ülkenin genel olarak kalkınmasını, özel kuruluşlarını, sivil toplum kuruluşlarını doğrudan etkilemektedir. Ulaştırma ve haberleşme hizmetlerinin zamanında karşılanması, eğitim ve sağlık hizmetlerinin yeterli düzeyde yerine getirilmesi, güvenlik hizmetlerinin hızı ve niteliği, yerel yönetim hizmetlerinin yeterliliği, yani genel olarak altyapı hizmetleri, diğer sektörlerin performans gösterebilmesinde kilit önemdedir. Özel işletmelerin mal ve hizmet kalitesini iyileştiremedikleri takdirde varlıkları sona erdiği gibi, kamu kurumları da, başarısızlık halinde ödedikleri vergilerle kamu hizmetlerini finanse eden vatandaşların tepkisi ile karşılaşmakta ve kamu yönetiminin yeniden düzenleme gerekliliği ortaya çıkabilmektedir.

Tabii ki kamu hizmetleri özel hizmetlerden farklıdır. Kamu kurumlarının genel eğilimleri, salt etkinliği sağlamaktan çok, topluma hizmet sunmaktır. Bu nedenle kamu yönetiminde mevcut performans yönetim tekniklerini kullanmakta belirli sınırlılıklar ortaya çıkabilmekle beraber bu kısıtlılıkların hiçbiri performans yönetim sistemlerinin kamu kurumlarında uygulanamayacağı anlamına gelmez. Sadece kamu kurum ve kuruluşlarında uygulanacak bireysel performans değerlendirme ve yönetim sistemlerinde, bu kısıtların dikkate alınması uygun olacaktır. Bununla birlikte, kamu çalışanlarının bireysel performanslarının değerlendirilmesinin vatandaş memnuniyetini artıracağı, kurumların performanslarının artacağı, motivasyonun sağlanacağı, kurum içi adalet duygusunun meydana geleceği, hizmet kalitesi ve kurumsal bağlılığını artacağ1, iç kontrol sistemi ve yönetişim uygulamalarının olumlu etkileneceği şeklinde kamuda bireysel performans değerlendirmesi yapılmasını destekleyen görüşler de ortaya konmaktadır.

Özel kuruluşlar, bugüne kadar sadece kamu kuruluşlarının tekelinde olan alanlara girmiş ve bu şekilde rekabet alanını genişletmiş̧tir. Kamu kuruluşları, özel kuruluşların yakaladığı kalite standartlarını yakalamak durumundadır. $\mathrm{Bu}$ standartlara ulaşılamaması bazı kamu kuruluşlarının mevcudiyetini sorgulanır hale getirebilir. Kamu kurumlarının güvenirliği ile sundukları kamu hizmetinin kalitesi arasında güçlü bir bağlantı vardir (Yerli, 2006: 65-67).

Eleştirel görüşlere rağmen, performans yönetim ve değerlendirmesi ile ilgili kaynak kitap ve yayınların büyük bölümünün iyi tasarlanan ve uygulanan performans değerlendirme sisteminin kurumların performans artışına katk1 sağlayacağ1 görüşü üzerinde birleştikleri görülmektedir. Devletin ve genel olarak kamu yönetiminin ekonomik ve toplumsal kalkınmada önemli rol oynamaya devam etmesi, özellikle ülkemiz için bir gereklilik durumundadır ki bu da kamu kurumlarının ve genel olarak kamu yönetiminin performans yönetimi ve bireysel performans değerlendirmesi modellerini tartı̧̧maya açmaktadır. 
Özel sektörle kamu kesimi arasında, kar amacı gütme, maliyetin karşılanma şekli, çalışan ve kurumsal yapı, müşteri-vatandaş ayrımı, siyasi etki, bürokrasinin olmaması, rekabet ortamının ve dolayısıyla kalitenin, sunulan mal ve hizmetin esas olması, çalışanları seçme, görevlendirme, ücretlendirme ve görevlerine son verme konusunda tamamen özgür ve esnek olunabilmesi gibi çok esaslı konularda farklılıklar bulunmaktadır. Bu durumlar performans değerlendirme sisteminin de bu farklılıklar dikkate alınarak yapılandırılması gerekliliğine işaret etmektedir (Tozlu, 2014: 75).

\subsection{Bireysel Performans Değerlendirmesini Zorlaştıran Durumlar}

Kamu görevlilerinin bireysel performanslarının değerlendirilmesi ile ilgili olarak önyarg1 nedeniyle değerlendirmenin tarafsız olamayacağı, stresi ve iş yükünü artıracağı, kurum içi huzurun bozulacağı, çalışanların sosyal hayatını olumsuz etkileyeceği, etik olmayan iş ve işlemlerin artacăğ, nitelikten niceliğe yöneliş olacağı şeklinde eleştiriler yapılmaktadır. Yine Devlet Memurları Kanununun (DMK) belirlediği sınıflandırma sistemi, farklı özellikler taşıyan çeşitli meslek ve uzmanlık dallarına aynı sınıf içinde yer verilmesine neden olduğundan bireysel performans değerlendirmesi açısından uygunluğu tartışılmaktadır.

Denetim hizmetleri, büro hizmetleri gibi birbiriyle nitelik ve eğitim açısından bağdaşmayan kadrolar genel idare hizmetleri sınıfi içerisinde bir arada bulunmaktadır. Bu durum, hizmetlerin gerektirdiği nitelikte çalışan istihdamını zorlaştırmaktadır. Eşit işe eşit ücret ilkesi uygulanabilmesi için ki bu evrensel kabul gören bir ilkedir, sınıfların daha dar tutulması gerekmektedir. Her sınıflandırma planında, hangi görevlerde, hangi yetkinlikte çalışan istihdam edileceği gösterilmeli ve güçlük ile sorumluluk dereceleri belirlenmelidir (Ergun, 2015: 256-257).

Rütbe sınıflandırmasında, maaşı/ücreti belirleyen, görevin mevkiidir. Kişiye verilen ücret, kişinin performansına göre değil 'mevkii'ne göredir. Kadro sınıflandırmasında, eşit işe eşit ücret yaklaşımı hakimdir, maaş/ücret, kişinin bulunduğu rütbeye göre değil, kişinin yaptığı işe, işin güçlük, sorumluluk derecesine göre belirlenir. (Kayar, 2016: 99). Türkiye'de memurlara uygulanan sistemin, rütbe sinıflandırması ve kapalı sistem olduğu söylenebilir. Ancak yetenekli kişilerin üst düzey yönetici kadrolarına getirilebilmeleri açık sistemin kısmi bir uygulaması olarak değerlendirilebilir (Nohutçu, 2016: 270-271). Bu noktada 657 sayılı DMK'da belirlenen sınıflandırma sisteminin bireysel performans değerlendirmesi yapılmasını zorlaştırdığı söylenebilir.

2005 tarihli Kamu Personel Kanunu Tasarısı Taslağında "Personel ve Başarı Değerlendirmesi” yani performans değerlendirmesi, sicil sistemi yerine önerildiği, taslağının toplu ücret artışı yerine bireysel performansa göre artışa yolacağı, rekabetin yardımlaşmayı azaltacağı, memurluk sisteminin "güvence" ve "kariyer" ilkesinin sözleşmelilik ve performansa dayalı değerlendirme ve ücretlendirme sistemi içinde eriyeceği (Sayan, 2007: 522-534) şeklinde performans değerlendirme sistemine olumsuz yaklaşımlar da ifade edilmektedir.

Kurum ya da çalışanların hedeflere ulaşılıp ulaşmadığının belirlenmesi bir anda mümkün olmadığından "kaliteye ulaşmak" gibi temel bir hedefi olan kamu kesiminde, anlık değerlendirmeyi zorlaşmaktadır. Yapısal farklılıklar nedeniyle özel sektörde ortaya çıkmış olan performans değerlendirme sisteminin kamu yönetimine uygulanmasında bazı güçlüklerle karşılaşılabilmektedir. Mevcut durumda Türkiye'de kamu kurumları için performans değerlendirme sisteminin uygulanmasını imkansız kılmasa da zorlaştıran temel sebepler birkaç madde halinde siralanabilir. Bunlar: 
$\checkmark$ Kalkınma Planı, Orta Vadeli Programlar ve Yıllık Programlarda performans değerlendirmesine değinilmekle birlikte Türkiye'de henüz konuya ilişkin çalışmalar taslak düzeyde olup, genel nitelikli yasal ve idari bir düzenleme bulunmamaktadır.

$\checkmark$ Kamu yönetiminde yaşanan değişim sürecinde mevzuata kazandırılan stratejik plan, performans programı, faaliyet raporu gibi uygulamaların kurumlar tarafından benimsenmesi ve hakkıyla yerine getirilmesi süreci halen devam etmektedir.

$\checkmark \quad$ Yerleşik statü hukuku sebebiyle, kamuoyunda ve bürokraside performans ölçüm ve değerlendirmesine karşı bir önyarg1 vardır. Bu nedenle performans yönetim sürecine ilişkin yöneticilere ve diğer çalışanlara bilgilendirme yapılmamaktadır (Tozlu, 2014: 75).

$\checkmark$ Yine 657 sayılı Yasada tanımlanan sınıflandırma sisteminin de bireysel performans değerlendirmesi yapılmasına uygun olmaması da önemli bir durumdur.

Çalışanların kamu veya özel sektör kurumlarından hangisini çalışmak için tercih ettikleri, kamuda uygulanması düşünülen performansa dayalı ücret planlarının üzerinde belirleyici bir rol oynamaktadır. Ancak bazen insanlar maaş/ücretin düşük olmasını göz ardı ederek, sosyal güvenlik gerekçeleri ya da başka sosyal nedenlerle kamu kurumlarında çalışmayı da isteyebilmektedirler (Yılmaz, 2004: 203).

\subsection{Yasal ve Yönetsel Düzenlemeler}

2005 yılında gündeme gelen Kamu Personel Reform Kanunu Taslağının 73. Maddesi personel başarı değerlendirme formlarını, 111. Maddesi ise performans ödemesini düzenlemekteydi.

$\mathrm{Bu}$ yasa taslağı çalışmaları sürecinde, 657 sayılı Yasada belirtilen memurlar için sicil raporu düzenlenmesi uygulaması, 2011 yılında yasa değişikliği ile kaldırılmıştır. Sicil raporları yöneticilere kendilerine bağlı olarak çalışan kamu görevlilerinin performans ve yetkinliklerini basitçe de olsa değerlendirme imkanı vermekteydi. Yine 6 y1l boyunca sicil raporunun olumlu olması halinde bir kademe ilerlemesi uygulamas1 yapılmas1 vb ödüllendirme mekanizmaları da öngörülmüştü. Sicil raporu uygulamasından vazgeçilmesi ile kamu görevlilerinin bireysel performans ve yetkinliklerinin değerlendirilmesine dair mevcut tek genel uygulama ortadan kaldırılmış olup yeni hali ile Yasanın 122. Maddesi, kamu kurum ve kuruluşlarının yürütmekte oldukları hizmetlerin özelliklerini göz önünde bulundurarak memurlarının başarı, verimlilik ve gayretlerini ölçmek üzere, Devlet Personel Başkanlığının uygun görüşü alınmak kaydıyla, değerlendirme ölçütleri belirlenebileceğini belirtmektedir. Sicil raporu uygulamasının kaldırılması ile kamu görevlilerine yönelik bireysel performans sistemi kurulması ve performans değerlendirmesi ihtiyacının somutlaştığı söylenebilir.

\subsubsection{Kalkınma Planı ve Orta Vadeli Programlar}

2014-2018 yıllarına ilişkin 10. Kalkınma Planında bireysel performans değerlendirme sistemi kurulmasına ilişkin bazı amaçlar belirtilmektedir. Bunlar, "kariyer gelişim ve performans değerlendirme sisteminin oluşturulması (10. Kalkınma Planı: 31,), “378. Bu gelişmelerle birlikte, kamuda istihdam türleri arasındaki farklılıkların giderilmesi, liyakata dayalı ve objektif işe alma ve terfi sisteminin oluşturulması, kısmi zamanlı çalışma imkânlarının geliştirilmesi, performans değerlendirme sisteminin oluşturulması," (10. Kalkınma Planı: 52), “384. Kamu personelinin verimliliğinin artırılması amacıyla etkin bir performans sistemi oluşturulacak ve hizmet, personel, ücret ilişkisi daha sağlıklı hale getirilecektir” (10. Kalkınma Planı: 53) şeklinde belirtilebilir. 
2018-2020 Orta Vadeli Programında ise, "öğretmenler için adaletli bir performans sistemi oluşturulacaktır." (2018-2020 Orta Vadeli Program: 46), "Vatandaşlara sunulan hizmetlerin hız ve kalitesi ölçülerek performans değerlendirmesi yapılacak ve sonuçlar kamuoyuyla paylaşılacaktır.” (2018-2020 Orta Vadeli Program: 62) amaçlarına yer verilmiştir.

11. Kalkınma Planında (s.180) "stratejik yönetim" başlığı altında "Performans denetimleri aracılığıyla kaynak kullanımının verimliliğine, etkililiğine ve ekonomikliğine dair kamuoyuna güvenilir bilgi sunularak kamuda hesap verebilirlik güçlendirilecektir" ibaresine yer verilmiştir.

Yine 2019-2021 OVP'de (s.24-26), yargıda performans esaslı izleme ve değerlendirme sistemi kurulacağ1, sağlı alanında kamu hastanelerinde, klinik kalite, vatandaş memnuniyeti, operasyonel etkinlik ve verimlilik alanlarında gösterilen performans sistematik biçimde takip edileceği ve sağlık personelinin teşvik mekanizmasının parçası hâline getirileceği, vatandaş memnuniyeti sonuçlarının kurumların ve sağlık çalışanlarının performans değerlendirmelerine dâhil edileceği belirtilmiştir. Üst politika belgelerinde bireysel performans değerlendirme sistemine yer verilmiş olması, Türk kamu yönetiminde bu uygulamaların daha geniş alan bulacağını göstermektedir.

\subsubsection{Kamu İç Kontrol Standartları}

26/12/2007 tarihli ve 26738 sayılı Resmi Gazetede yayımlanarak yürürlüğe giren Kamu İç Kontrol Standartları Tebliği ile Kamu kurumları için zorunlu tutulan Kamu İç Kontrol Standartlarına bakıldığında, 3.6. numaralı Kamu İç Kontrol Şartının, "Personelin yeterliliği ve performansı bağlı olduğu yöneticisi tarafından en az yılda bir kez değerlendirilmeli ve değerlendirme sonuçları personel ile görüşülmelidir." şeklinde belirlendiği, 3.7. numaralı Kamu İç Kontrol Şartının, "Performans değerlendirmesine göre performansı yetersiz bulunan personelin performansını geliştirmeye yönelik önlemler alınmalı, yüksek performans gösteren personel için ödüllendirme mekanizmaları geliştirilmelidir." şeklinde belirlendiği görülmektedir. Amirleri tarafından performansı düşük olarak belirlenen personele zayıf oldukları alanlarda hizmet içi eğitim verilmesi, iş gücü verimliği açısından olumlu olacaktır (Erbaş, 2015: 96-97).

\subsubsection{Kamu Personelinin Değerlendirilmesine İlişkin Yönetmelik Taslağı}

Kamu Personelinin Başarılarının Değerlendirilmesine İlişkin Yönetmelik Taslağında, Devlet memurları ile sözleşmeli personelin değerlendirilmesine ilişkin usul ve esasların belirlenmesi amacıyla hazırlandığ belirtilmiş, kamu kurum ve kuruluşlarında görevli 657 sayılı Devlet Memurları Kanununa tabi olarak istihdam edilen Devlet memurları ile 399 sayılı Kanun Hükmünde Kararnameye tabi sözleşmeli personel hakkında uygulanacağ belirtilmiştir.

Başarı değerlendirme, Bir değerlendirme dönemi içinde personelin başarı, verimlilik ve gayretleri ile gelişim ihtiyaçlarının tespit edilmesine yönelik olarak hedef, görev ve yetkinliklerinin, belirlenmiş ölçütler çerçevesinde ve belirli bir değerlendirici veya değerlendiriciler tarafından izlenerek değerlendirildiği süreçler olarak tanımlanmıştır.

Değerlendirme düzeyleri
$\checkmark$ (A) düzeyi (90-100 Puan) 

$\checkmark$ (B) düzeyi (76-89 Puan)
$\checkmark$ (C) düzeyi (60-75 Puan)
$\checkmark$ (D) düzeyi (0-59 Puan) olarak gösterilmektedir.

Yine aynı yönetmelik taslağında, değerlendirme planlarının hazırlanacağı, izleme süreci yürütüleceği, geri bildirim yapılacağı belirtilip değerlendirme sürecinin açıklandığı, hedeflerin değerlendirilerek hedef puanı belirleneceği, görevlerin değerlendirilerek görev puanı verileceği, yetkinliklerin değerlendirilerek yetkinlik puanı verileceği, kamu hizmetlerinin değerlendirilerek vatandaş memnuniyeti puanı belirleneceği, sonuçta başarı puanının ortaya çıkacağı, birbirini takip eden üç başarı değerlendirme döneminde başarı puanı A ve B düzeyinde yer alan personelin bu durumu görevde yükselmelerinde, göreviyle ilgili kişisel gelişim imkânlarının desteklenmesinde, yer değiştirme uygulamalarında, yurt dışı görevlendirmelerde ve insan kaynakları planlamasının diğer alanlarında esas alınacağı, sözleşmeli personelden başarı puanı A, B ve C düzeyinde olanlara 22/01/1990 tarihli ve 399 say1lı Kanun Hükmünde Kararnamenin 43 üncü maddesi hükümleri çerçevesinde başarı ücreti ödeneceği, C ve D düzeyinde başarı puanı alan personelin eksikliklerinin tespit edildiği alanlarda amir ile personel arasında görüşme yapılarak gelişim planlarının hazırlanacağı, birbirini takip eden üç başarı değerlendirme döneminin en az ikisinde başarı puanı D düzeyinde olan personel hakkında kurumlar görev veya görev yeri değişikliği gibi gerekli tedbirleri alacağı, çalışma grubu başarısı ölçümü yapılacağı belirtilmektedir (Kamu Personelinin Başarılarının Değerlendirilmesine İlişkin Genel Yönetmelik Taslağı, Erişim: 09/01/2021).

Kalkınma Bakanlığının yayımladığı Kamuda İnsan Kaynakları Yönetimi Çalışma Raporunda, şu anda kamu insan kaynakları yönetiminde en önemli eksiklerden birisinin etkili kamu hizmeti sunumunu destekleyecek bir personel değerlendirme sisteminin bulunmayışı olduğu belirtilmiştir (Kalkınma Bakanlığı, 2018:17).

\subsection{Stratejik Plan ve Bireysel Performansın Birlikte Değerlendirilmesi}

Bireysel performans değerlendirmesi, stratejik yönetim ve planlama ile bir bütünün parçaları gibidir. Bir kurumda stratejik plan ile kurumsal amaç, hedef ve stratejiler ve performans göstergeleri belirlenmeden yine bu kurumsal amaç ve hedefler, birimsel ve bireysel amaç ve hedeflere dönüştürülmeden kurumsal ve bireysel performans ölçümü ve değerlendirmesi yapılması mümkün değildir. Zira performansın karşılaştırılabileceği kurumsal ve bireysel amaç ve hedefler ile performans gösterge ve standartlarına ihtiyaç vardır. Stratejisi olmayan bir kurum ise denizde önünü göremeyen ve yönü belli olmayan bir gemi gibidir. Bireysel performans değerlendirme sonuçları, stratejik planda ortaya konan hedeflere ne derecede ulaşılabildiğini, kurumun genel olarak ya da çalışanların bireysel olarak hedeflerine ulaşmada ne kadar başarılı olduğunu gösterdiğinden aslında stratejik planın izlenmesi sürecinde önemli bir görev icra etmektedir. Yine stratejik planın süresi dolduğunda yeniden hazırlanması ya da yenilenmesi süreçlerinde, bireysel performans değerlendirme sonuçlarından faydalanılması yeni hazırlanan stratejik planın uygulanabilirliği ve başarısı açısından çok ciddi katkıda bulunacaktır.

Kamu kurumlarında en önemli sorunlardan biri, nitelikli insan kaynağı eksikliği, nitelikli insan kaynağının kullanılamaması ve ölçülebilir performans kriterlerinin olmamasıdır. Bu nedenle, kamu yönetimini yeniden düzenleme çalışmaları da kurumların insan kaynakları ile kurumsal ve bireysel performansları üzerinde yoğunlaşmaktadır (Özkaya, 2013: 49). 
Kurumlar, stratejik plan ile belirlenen genel hedeflerin, bu hedefleri gerçekleştirecek yönetici ve çalışanlara iletilmesi amacıyla resmi performans değerlendirme sistemi oluştururlar. Örneğin bir Kurumun stratejik planı, yeni proje ya da faaliyet uygulanmasını ya da yeni planlar yapılmasını ön görüyorsa bu hedeflerin gerçekleştirilmesi için kurumda pek çok birimden pek çok çalışanın katılımı ve katkısı gerekmektedir. Genel amaç, stratejik plan kesinleştikten sonra bu amaca ulaşmak için gerekli faaliyetleri, projeleri ve planları birimlere dağıtırlar. Her birim kendi hedefleri doğrultusunda çalışanları arasında görev dağılımı yaparak ve bu stratejik planın uygulanmasına yardım ederek hedeflerin bireysel düzeyde belirlenmesi ve gerçekleştirilmesi sürecini yürütürler. Böylece kurum stratejik planları, bireysel hedefler ve planlar haline dönüştürülerek genel amaçlar gerçekleştirilir. Performans yönetimi sistemi ve bireysel performans hedeflerinin belirlenmesi faaliyeti kurumların stratejik planları ile yakından ilişkili olup her iki sistemin etkinliği önemli ölçüde birbirine bağlıdır (Uyargil, 2017:2-3).

Yine kurumsal performans değerlendirmesi ile bireysel performans değerlendirmesi arasında bağlantı kurulması stratejik planların başarıyla uygulanmasında önemlidir. Örneğin Sağlık Bakanlığı performansa dayalı ek ödeme sistemi, sadece ek ödeme modeli olmanın ötesinde "başarı ölçütlerine" göre personeli ödüllendirerek bireysel verimliliği etkilemekte, "kurumsal performans kriterleri" ile ilişkilendirerek sağl1k kuruluşun verimlilik ve etkinliğini artırmaya da katkı sağlamaktadır (Aydın ve Demir, 2007: 59). Sağlık Bakanlığının performans değerlendirme sistemi, hem hasta odaklı hem de çalışan odaklı amaçların gerçekleştirilmesini esas almakta, kurumsal performans ölçümünde hasta güvenliği, laboratuvar güvenliği, hasta hakları ve tesis güvenliği gibi hedefleri kapsamaktadır. Kurumsal performans ölçümü ile elde edilen kat sayı ile çalışanlara ödenen performansa dayalı ek ödeme arasında bağlantı kurulmuştur (Güler vd., 2014:6-8).

Çalışanların bireysel performans hedef ve göstergelerini belirlemek, bireysel performanslarını ölçmek ya da değerlendirmek; stratejik plandaki genel amaç ve hedefler ile göstergeler olmaksızın mümkün değildir. Yine stratejik plan performans gösterge ve hedeflerini içerdiğinden bireysel performans değerlendirmesi stratejik planın izlenmesi açısından elzemdir. Bu nedenle, bireysel performans sistemi ile stratejik plan arasında çok önemli bir bağlantı olduğu söylenebilir.

\section{STRATEJIKK PLAN İLE BİREYSEL PERFORMANS ÍLISSTKISİNE DAİR SAĞLIK BAKANLIĞI ÇALIŞANLARININ ALGISI HAKKINDA ARAŞTIRMA}

Araştırmada anket yöntemi kullanılmıştır. Sağlık Bakanlığı merkez teşkilatında 263 kişinin katılımı ile yapılan anket çalışmasında, 5'li likert ölçeği kullanılmıştır. Anketin 2. Bölümünde bireysel performans değerlendirmesi hakkında olumlu algılar içeren 10 soru, 3. Bölümünde olumsuz algılar içeren 10 soru yöneltilmiştir.14. Bölümünde stratejik plan, bireysel performans ilişkisine dair 7 soru, 13. Bölümde 1 soru katılımc1lara yöneltilmiş olup 263 katılımcının anket formlarından elde edilen veriler SPSS 21 programına aktarılarak analiz edilmiştir.

\subsection{Anket Katılımcılarına İlişkin Genel Bilgiler}

Ankete katılanların yaş aralığı, cinsiyeti, eğitim, gelir durumu, hizmet süresi, pozisyonu gibi bilgiler Tablo 1'de gösterilmektedir: 
Tablo 1. Anket Katılımcıları Genel Bilgiler

\begin{tabular}{|c|c|c|c|}
\hline Değişken & Kategori & Frekans & (\%) \\
\hline \multirow[t]{2}{*}{ Cinsiyet } & Kadın & 117 & $\% 44,5$ \\
\hline & Erkek & 146 & $\% 55,5$ \\
\hline \multirow[t]{4}{*}{ Yaş } & 20-30 arası yaş aralığı & 62 & $\% 23,57$ \\
\hline & 31-40 arası yaş aralığı & 97 & $\% 36,88$ \\
\hline & 41-50 arası yaş aralığı & 77 & $\% 29,27$ \\
\hline & 51-65 arası yaş aralığı & 27 & $\% 10,26$ \\
\hline \multirow[t]{4}{*}{ Eğitim Durumu } & Lise & 10 & $\% 3,8$ \\
\hline & Üniversite & 133 & $\% 50,57$ \\
\hline & Yüksek lisans & 88 & $\% 33,46$ \\
\hline & Doktora & 32 & $\% 12,16$ \\
\hline \multirow[t]{4}{*}{ Hizmet Süresi } & 10 yıldan az & 102 & $\% 38,78$ \\
\hline & $10-20$ yıl arası & 85 & $\% 32,31$ \\
\hline & $21-30$ yıl arası & 56 & $\% 21,29$ \\
\hline & 30 yıldan fazla & 20 & $\% 7,6$ \\
\hline \multirow[t]{4}{*}{ Aylık Geliri } & 1.500-2.500 TL arası & 14 & $\% 5,32$ \\
\hline & $2.501-4.000 \mathrm{TL}$ & 69 & $\% 26,23$ \\
\hline & 4.001-6.000 TL & 101 & $\% 38,4$ \\
\hline & 6.001 TL üzeri & 79 & $\% 30,03$ \\
\hline \multirow[t]{4}{*}{ Pozisyonu } & Üst Düzey Yönetici & 9 & $\% 3,42$ \\
\hline & Orta-Alt Düzey Yönetici & 30 & $\% 11,4$ \\
\hline & Müfettiş/Denetçi/İç Denetçi & 70 & $\% 26,61$ \\
\hline & Yönetici Olmayan Çalışanlar & 154 & $\% 58,55$ \\
\hline
\end{tabular}

\subsection{Anket Araştırmasının Geçerliliği ve Güvenilirliği}

Anketin genel güvenilirliğine ilişkin Cronbach's Alpha değerinin \%94,6 olduğu Tablo 2'de gösterilmekte olup anketin güvenilirlik düzeyinin yüksek oranda olduğu söylenebilir.

Tablo 2. Anket Genel Güvenilirlik Oranı

\begin{tabular}{|c|c|c|c|c|}
\hline \multicolumn{2}{|c|}{ Cronbach's Alpha } & \multicolumn{2}{|c|}{$\begin{array}{l}\text { Cronbach's Alpha } \\
\text { Based on } \\
\text { Standardized Items }\end{array}$} & $\mathrm{N}$ of Items \\
\hline ,946 & & 958 & & 83 \\
\hline \multicolumn{5}{|c|}{ Hotelling's T-Squared Test } \\
\hline $\begin{array}{l}\text { Hotelling's T- } \\
\text { Squared }\end{array}$ & $F$ & df1 & df2 & Sig \\
\hline 2050,648 & 17,276 & 82 & 181 &, 000 \\
\hline
\end{tabular}


Tablo 3'te gösterildiği gibi KMO değeri 0,92 olarak hesaplanmıştır ve bu değer örneklem büyüklügünün faktör analize uygun olduğunu göstermektedir. Küresellik varsayımını test eden $X^{2}$ değeri=15404,04 olarak hesaplanmıştır. $\mathrm{Bu}$ değere karş1lık gelen $\mathrm{p}$ değeri $0,00<0,05$ olduğundan değerlerin anlamlı olduğu görülmektedir.

Tablo 3. Örneklem Yeterliliği KMO and Barlett's Testi Sonucu

\begin{tabular}{|l|l|l|}
\hline \multicolumn{2}{|l|}{ Kaiser-Meyer-Olkin Örneklem Yeterliliği Ölçüsü } &, 920 \\
\hline & Approx. Chi-Square & 15404,084 \\
\cline { 2 - 3 } & Df & 3486 \\
\cline { 2 - 3 } Bartlett's Test of Sphericity & Sig. &, 000 \\
\cline { 2 - 3 } & Df & 3486 \\
\cline { 2 - 3 } & Sig. & 000 \\
\hline
\end{tabular}

\subsection{Hipotezin Analizi}

H0:Kamu kurumlarında kamu görevlilerinin stratejik plan hakkında bilgi sahibi olması ile kamu kurumlarında bireysel performans yönetim ve değerlendirme sistemi kurulmasına ilişkin olumlu algılar arasında anlamlı bir bağlant1 yoktur.

H1: Kamu kurumlarında kamu görevlilerinin stratejik plan hakkında bilgi sahibi olması ile kamu kurumlarında bireysel performans yönetim ve değerlendirme sistemi kurulmasına ilişkin olumlu algılar arasında anlamlı bir bağlantı vardır.

Tablo 4'te görüldüğü gibi $\mathrm{P}$ değeri (sig. değeri) $0,00<0.05$ olduğu için H0 hipotezi reddedilir. Kamu kurumlarında kamu görevlilerinin stratejik plan hakkında bilgi sahibi olması ile kamu kurumlarında bireysel performans yönetim ve değerlendirme sistemi kurulmasına ilişkin olumlu algılar arasında anlamlı bir bağlantı olduğu \%95 güven seviyesinde söylenebilir. H1 doğrulanmaktadır.

Tablo 4. Pearson Korelasyon Testi

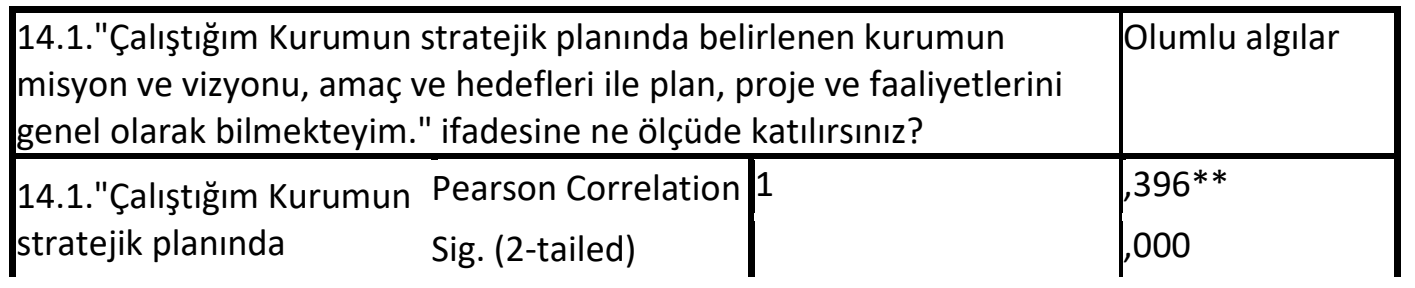




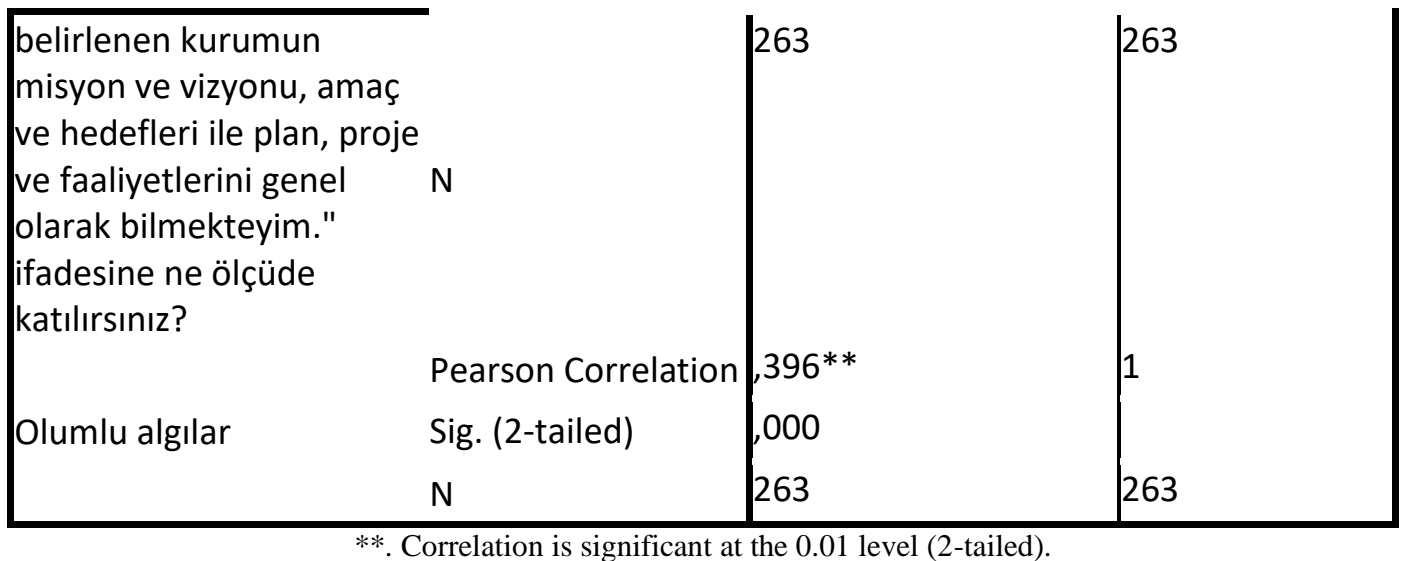

Stratejik plan ile ilgili olarak bilgi sahibi olduğunu belirtenler ile bilgi sahibi olmadığını belirtenlerin bireysel performans değerlendirmesine ilişkin olumlu ve olumsuz algıları karşılaştırıldığında ise;

Tablo 5. Grup İstatistikleri

\begin{tabular}{|c|c|c|c|c|c|c|}
\hline \multicolumn{3}{|c|}{$\begin{array}{l}\text { 14.1."Çalıştığım Kurumun stratejik planında } \\
\text { belirlenen kurumun misyon ve vizyonu, } \\
\text { amaç ve hedefleri ile plan, proje ve } \\
\text { faaliyetlerini genel olarak biliyor musunuz? }\end{array}$} & \multirow{2}{*}{$\frac{N}{222}$} & \multirow{2}{*}{$\frac{\text { Mean }}{4,1014}$} & \multirow{2}{*}{$\frac{\text { Std. Deviation }}{\text {,86842 }}$} & \multirow{2}{*}{$\frac{\text { Std. Error Mean }}{, 05828}$} \\
\hline Olumlu algılar & dimoncinn & Evet & & & & \\
\hline & 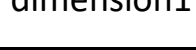 & Hayır & 41 & 3,3146 & 1,14903 & 17945 \\
\hline \multirow[t]{2}{*}{ Olumsuz algılar } & \multirow{2}{*}{ dimension1 } & Evet & 222 & 3,2617 & ,91904 & 06168 \\
\hline & & Hayır & 41 & 3,5683 & , 81408 & 12714 \\
\hline
\end{tabular}

Olumlu algılara ilişkin, Tablo 5'te görüldüğü üzere, stratejik plan hakkında bilgi sahibi olduğunu söyleyen 222 kişinin bireysel performans değerlendirme süreci hakkında olumlu algılar ile ilgili sorulara vermiş oldukları cevapların ortalamasının 4,1014 olduğu görülmektedir. Stratejik plan hakkında bilgi sahibi olmadığını söyleyen 41 kişinin bireysel performans değerlendirme süreci hakkında olumlu algılar ile ilgili sorulara vermiş oldukları cevapların ortalamasının 3,3146 olduğu görülmektedir. 5'li likert ölçeğinde en yüksek puanın 5 olduğu göz önüne alarak, stratejik plan hakkında bilgi sahibi olduğunu söyleyen kişilerin, bilgi sahibi olmadığını söyleyen kişilere göre olumlu algılarla ilgili sorulara daha pozitif yaklaştığı görülmektedir. Ayrıca bilgi sahibi olduğunu söyleyen kişilerin standart sapmasının, bilgi sahibi olmadığını söyleyen kişilerin standart sapmasına göre düşük olduğu görülmektedir. Bu nokta bizi bilgi sahibi olduğunu söyleyen kişilerin cevaplarının bilgi sahibi olmadığını söyleyen kişilerin cevaplarına göre birbirine daha yakın olduğu yorumuna götürmektedir.

Olumsuz algılara ilişkin, stratejik plan hakkında bilgi sahibi olduğunu söyleyen 222 kişinin bireysel performans değerlendirme süreci hakkında olumsuz algılar ile ilgili sorulara vermiş oldukları cevapların ortalamasının 3,2617 olduğu görülmektedir. Stratejik plan hakkında bilgi sahibi olmadığını söyleyen 41 kişinin bireysel performans değerlendirme süreci hakkında olumsuz algılar ile ilgili sorulara vermiş oldukları cevapların 
ortalamasının 3,5684 olduğu görülmektedir. Bilgi sahibi olduğunu ifade eden kişilerin, bilgi sahibi olmadığını söyleyen kişilere göre olumsuz algılarla ilgili düşüncelere daha düşük ortalamayla yaklaştığı, yani olumsuz algılara olumlu algılardaki gibi beklenilen yönde cevap verdikleri görülüyor. Ayrıca bilgi sahibi olduğunu söyleyen kişilerin standart sapmasının, bilgi sahibi olmadığını söyleyen kişilerin standart sapmasından çok farklı olmadığı görülmektedir. Bilgi sahibi olanlar da olmayanlar da kendi grupları içinde birbirine yakın cevaplar verdiği anlaşılmaktadır.

Stratejik plan hakkında bilgi sahibi olan kişilerin olumlu algılara yüksek puan verdiği, olumsuz algılara düşük puan verdiği görülmektedir. Bu bize stratejik plan hakkında bilgi sahibi olan kişilerin bireysel performans değerlendirmesi ile ilgili olumsuz algılarının kırıldığını ve daha pozitif bir yaklaşım içerisinde olduklarını gösterdiği söylenebilir. Stratejik plan hakkında bilgi sahibi olmayan kişilerin ise bireysel performans değerlendirmesi ile ilgili olumlu algılara düşük ortalamayla cevap verdiği yine olumsuz algılara daha yüksek ortalamayla cevap verdikleri göz önüne alındığında, bu kişilerin bireysel performans değerlendirmesi ile ilgili algılarının stratejik plan hakkında bilgi sahibi olanlara göre daha negatif yönde olduğu söylenebilir.

\subsection{Stratejik Plan-Bireysel Performans İlişkisi}

Anket çalışmasına katılanların yaklaşık \% 75,66'sı stratejik planın mevcudiyetinin çalışanların bireysel performansını artırdığ 1 algısını taşımaktadır.

Tablo 6. Stratejik Plan-Bireysel Performans İlişkisi

\begin{tabular}{|c|c|c|c|}
\hline Anket Sorusu & Cevap & Frekans & $\begin{array}{l}\text { Yüzde } \\
(\%)\end{array}$ \\
\hline \multirow{5}{*}{$\begin{array}{l}\text { Stratejik planın mevcut olması yani } \\
\text { amaç ve hedefler ile bunlara ulaşmak } \\
\text { için proje, faaliyet ve planların } \\
\text { belirlenmiş olması çalışanların } \\
\text { bireysel performansını artırmaktadır. }\end{array}$} & Katıliyorum & 109 & 41,44 \\
\hline & Kismen Katıliyorum & 90 & 34,22 \\
\hline & Fikrim Yok & 27 & 10,27 \\
\hline & Kismen Katılmiyorum & 18 & 6,84 \\
\hline & Katılmiyorum & 19 & 7,22 \\
\hline
\end{tabular}

\subsection{Stratejik Planda Katılımcılık ve Bireysel Performans}

Anket çalışmasına katılanların yaklaşık \% 85,17'si stratejik plana çalışan katılımının çalışanların bireysel performansını artırdığı algısını belirtmişlerdir.

Tablo 7. Stratejik Planda Katılımcılık ve Bireysel Performans

\begin{tabular}{|c|c|c|c|}
\hline Anket Sorusu & Cevap & Frekans & $\begin{array}{c}\text { Yüzde } \\
(\%)\end{array}$ \\
\hline \multirow{5}{*}{$\begin{array}{l}\text { Stratejik planlarda ortaya konan amaç } \\
\text { ve hedefler ile proje ve faaliyetlerin } \\
\text { belirlenmesi sürecinde çalışan } \\
\text { katılımının sağlanması ve görüşünün } \\
\text { alınması çalışanların bireysel } \\
\text { performansını artırmaktadır. }\end{array}$} & Katıliyorum & 147 & 55,89 \\
\hline & Kismen Kat1liyorum & 77 & 29,28 \\
\hline & Fikrim Yok & 22 & 8,37 \\
\hline & Kismen Katılmiyorum & 8 & 3,04 \\
\hline & Katılmıyorum & 9 & 3,42 \\
\hline
\end{tabular}




\subsection{Stratejik Planın Çalışanlara Bildirimi-Bireysel Performans İlişsisi}

Anket çalışmasına katılanların yaklaşık \% 77,57'si stratejik plan kapsamında çalışanlara görevlendirme yapılmasının, çalışanların bireysel performansını artırdığına katıldığını belirtmişlerdir.

Tablo 8. Stratejik Planın Çalışanlara Bildirimi-Bireysel Performans İlişkisi

\begin{tabular}{|c|c|c|c|}
\hline Anket Sorusu & Cevap & Frekans & $\begin{array}{c}\text { Yüzde } \\
(\%)\end{array}$ \\
\hline \multirow{5}{*}{$\begin{array}{l}\text { Stratejik planda amaç ve hedefler ile } \\
\text { proje, faaliyet ve planların } \\
\text { belirlenmesi sonrasında çalışanlara } \\
\text { resmi olarak bildirim ve } \\
\text { görevlendirme yapılması, bütün } \\
\text { çalışanların bireysel performansını } \\
\text { artırmaktadır. }\end{array}$} & Katıliyorum & 118 & 44,87 \\
\hline & Kismen Kat1liyorum & 86 & 32,7 \\
\hline & Fikrim Yok & 31 & 11,79 \\
\hline & Kismen Katılmiyorum & 15 & 5,7 \\
\hline & Kat1lmıyorum & 13 & 4,94 \\
\hline
\end{tabular}

\subsection{Stratejik Planın İzlenmesi ve Bireysel Performans}

Anket çalışmasına katılanların yaklaşık \% 79,85'i stratejik planın düzenli izlemesinin yapılmasının bireysel performansı artırıcı etki oluşturduğuna kısmen ya da tamamen katılmaktadır.

Tablo 9. Stratejik Planın İzlenmesi ve Bireysel Performans

\begin{tabular}{|c|c|c|c|}
\hline Anket Sorusu & Cevap & Frekans & $\begin{array}{l}\text { Yüzde } \\
\text { (\%) }\end{array}$ \\
\hline \multirow{5}{*}{$\begin{array}{l}\text { Stratejik planda belirtilen amaç ve } \\
\text { hedeflere ulaşmak için belirlenen proje } \\
\text { ve faaliyetler ile planların düzenli } \\
\text { izleme/takibinin yapılması bireysel } \\
\text { performansı } \\
\text { olusturmaktadır. }\end{array}$} & Katıliyorum & 112 & 42,59 \\
\hline & Kismen Kat1liyorum & 98 & 37,26 \\
\hline & Fikrim Yok & 33 & 12,55 \\
\hline & Kısmen Katılmıyorum & 13 & 4,94 \\
\hline & Katılmıyorum & 7 & 2,66 \\
\hline
\end{tabular}

\subsection{Stratejik Planın Başarısı ve BPD}

Anket çalışmasına katılanların ise yaklaşık \% 55,89'si amaç ve hedeflere beklenildiği şekilde ulaşılamamasının nedenleri arasında bireysel performans değerlendirmesi yapılmamasının en önemli nedenler arasında yer aldığ algısına sahiptir. Diğer sorulara göre katılma oranındaki düşüklüğün nedeni başarıya ulaşmanın önünde bireysel performans değerlendirmesi olmamasından başka sebeplerin de olduğu görüşünden kaynaklandığ düşünülmüştür.

Tablo 10. Stratejik Planın Başarısı ve Performans Değerlendirmesi

\begin{tabular}{|l|l|l|l|}
\hline Anket Sorusu & Cevap & Frekans & $\begin{array}{l}\text { Yüzde } \\
(\%)\end{array}$ \\
\hline & Kat1lyyorum & 48 & 18,25 \\
\hline
\end{tabular}




\begin{tabular}{|l|l|l|l|}
\hline Stratejik planda belirlenen başar1 & K1smen Katılıyorum & 99 & 37,64 \\
\cline { 2 - 4 } kriterleri ve performans göstergelerine & Fikrim Yok & 43 & 16,35 \\
\cline { 2 - 4 } ulaşlamaması yani amaç ve hedeflere & K1smen Katılmıyorum & 39 & 14,83 \\
\cline { 2 - 4 } $\begin{array}{l}\text { beklenildiği şekilde ulaşılamamasının } \\
\text { nedenleri arasında bireysel performans } \\
\text { değerlendirmesi yapılmaması en önemli } \\
\text { nedenler arasında yer almaktadır. }\end{array}$ & Katılmıorum & 34 & 12,93 \\
& & & \\
\hline
\end{tabular}

\subsection{DMK Sinıflandırma Sistemi ve BPD}

Anket çalışmasına katılanların yaklaşık \% 49,81'i hali hazırda uygulanan sınıflandırma ve sınıflandırmaya dayalı ücret sisteminin, gelecekte uygulanması muhtemel bir bireysel performans değerlendirme ve yönetim sisteminin uygulanmasını olumsuz etkileyeceği algısını belirtmiştir.

Tablo 11. DMK Sınıflandırma Sistemi ve Performans Değerlendirmesi

\begin{tabular}{|c|c|c|c|}
\hline Anket Sorusu & Cevap & Frekans & $\begin{array}{l}\text { Yüzde } \\
(\%)\end{array}$ \\
\hline \multirow{5}{*}{$\begin{array}{l}\text { Devlet Memurları Kanununda halihazırda } \\
\text { uygulanan sinıflandırma ve sinıflandırmaya } \\
\text { dayalı ücret sistemi, gelecekte uygulanması } \\
\text { muhtemel bir bireysel performans değerlendirme } \\
\text { ve yönetim sisteminin uygulanmasını olumsuz } \\
\text { etkileyecektir. }\end{array}$} & Katıliyorum & 56 & 21,29 \\
\hline & Kismen Katıliyorum & 75 & 28,52 \\
\hline & Fikrim Yok & 63 & 23,95 \\
\hline & $\begin{array}{l}\text { Kismen } \\
\text { Katılmiyorum }\end{array}$ & 35 & 13,31 \\
\hline & Katılmiyorum & 34 & 12,93 \\
\hline
\end{tabular}

\subsection{BPD Sonuçlarının Stratejik Planlama Sürecine Aktarılması}

Anket çalışmasının 13. Bölümünde yer alan anket sorusuna ilişkin olarak, Anket çalışmasına katılanların yaklaşık \% 81,75'i bireysel performans değerlendirme sistemi sonuçlarının, "Stratejik Planlama" işlemlerinde dikkate alınması gerektiği görüşüne katılmışlardır.

Tablo 12. BPD Sonuçlarının Stratejik Planlama Sürecine Aktarılması

\begin{tabular}{|l|l|l|l|}
\hline Anket Sorusu & Cevap & Frekans & $\begin{array}{l}\text { Yüzde } \\
(\%)\end{array}$ \\
\hline \multirow{2}{*}{$\begin{array}{l}\text { Bireysel performans değerlendirme sistemi } \\
\text { sonuçları, "Stratejik Planlama" işlemlerinde } \\
\text { dikkate alınmalıdır. }\end{array}$} & Katılıyorum & 136 & 51,71 \\
\cline { 2 - 4 } & Kismen Katılıyorum & 79 & 30,04 \\
\cline { 2 - 4 } & Fikrim Yok & 34 & 12,93 \\
\cline { 2 - 4 } & Kismen Katılmıyorum & 6 & 2,28 \\
\cline { 2 - 4 } & Katılmıorum & 8 & 3,04 \\
\hline
\end{tabular}




\section{SONUÇ}

Anket araştırması sonuçlarına göre kamu çalışanlarının stratejik plan hakkında bilgi sahibi olması ile kamu kurumlarında bireysel performans yönetim ve değerlendirme sistemi kurulmasına ilişkin olumlu algının artması arasında anlamlı bir bağlantı olduğu söylenebilir. Stratejik plan hakkında bilgi sahibi olan kişilerin bireysel performans değerlendirmesi ile ilgili olumsuz algılarının kırıldığı ve daha pozitif bir yaklaşım içerisinde oldukları söylenebilir.

Stratejik planı hakkında bilgi sahibi olmayan kişilerin ise bireysel performans değerlendirmesi ile ilgili olumlu algilara düşük ortalamayla cevap verdiği yine olumsuz algılara daha yüksek ortalamayla cevap verdikleri, bu kişilerin bireysel performans değerlendirmesi ile ilgili algılarının stratejik plan hakkında bilgi sahibi olanlara göre daha negatif yönde olduğu söylenebilir. Stratejik plan hakkında bilgi sahibi olmak ile bireysel performans değerlendirmesine ilişkin algı arasında doğrudan bir bağlantı olduğu söylenebilir.

Yine anket çalışmasından, stratejik planın mevcut olmasının yani amaç ve hedefler ile bunlara ulaşmak için proje, faaliyet ve planların belirlenmiş olmasının çalışanların bireysel performansını artırdığı, stratejik planda belirtilen amaç ve hedeflere ulaşmak için belirlenen proje ve faaliyetler ile planların düzenli izleme/takibinin yapılmasının bireysel performansı artırıcı etki oluşturduğu, stratejik planların hazırlanmasında katılımcılığın sağlanması halinde bireysel performansın olumlu etkilendiği, stratejik planda amaç ve hedefler ile proje, faaliyet ve planların belirlenmesi sonrasında çalışanlara resmi olarak bildirim ve görevlendirme yapılmasının, bütün çalışanların bireysel performansını artırdığı, stratejik planda belirlenen amaç ve hedeflere beklenildiği şekilde ulaşılamamasının nedenleri arasında bireysel performans değerlendirmesi yapılmamasının en önemli nedenler arasında yer aldığı, Devlet Memurları Kanununda halihazırda uygulanan sınıflandırma ve sınıflandırmasının bireysel performans değerlendirmesine çok uygun olmadığı görüşlerine anket katılımcılarının ciddi boyutta katıldığı ve yine bireysel performans değerlendirme sistemi sonuçlarının, stratejik planlama işlemlerinde dikkate alınması gerektiği yönünde yaygın kanaat olduğu anlaşılmaktadır. Bu bulgular da stratejik plan ile kamu çalışanlarının bireysel performansları ve bireysel performans değerlendirmesi arasında bir ilişki olduğunu göstermektedir. Çalışanların bireysel performans hedef ve göstergelerini belirlemek, bireysel performanslarını ölçmek ya da değerlendirmek; stratejik plandaki genel amaç ve hedefler ile göstergeler olmaksızın mümkün değildir. Yine stratejik plan performans gösterge ve hedeflerini içerdiğinden bireysel performans değerlendirmesi stratejik planın izlenmesi açısından önemlidir. $\mathrm{Bu}$ nedenle, stratejik plan ile bireysel performans ve bireysel performans değerlendirmesi arasında iki yönlü bir ilişki olduğu, yani stratejik planın bireysel performansı ve bireysel performans değerlendirmesini etkilediği, aynı şekilde stratejik planın da bireysel performans ve bireysel performans değerlendirmesinden etkilendiği söylenebilir.

Kurumların, stratejik planda belirtilen amaç ve hedeflerin, bu hedefleri gerçekleştirecek yönetici ve çalışanlara aktarılması amacıyla performans değerlendirme sistemi oluşturmaları stratejik planın başarısı için önemlidir. Örneğin bir kurumun stratejik planı, yeni proje ya da faaliyet gerçekleştirilmesini ya da yeni planlar yapılmasını öngörmüşse bu hedeflerin gerçekleştirilmesi için kurum içinden bazı birim ve bazı çalışanların katılımı ve katkısı gerekmektedir. Her birim kendi hedefleri doğrultusunda çalışanları arasında görev dağılımı yaparak ve stratejik planın uygulanmasına yardım ederek hedeflerin bireysel düzeyde belirlenmesi ve gerçekleştirilmesi sürecini yürütmelidir. Böylece kurum stratejik planları, bireysel hedefler ve planlar haline dönüştürülerek genel amaçların gerçekleştirilmesi sağlanır. Performans yönetimi sistemi ve bireysel performans hedeflerinin 
belirlenmesi faaliyeti, kurumların stratejik planları ile yakından ilişkili olup her iki sistemin etkinliği önemli ölçüde birbirine bağlıdır. Bu noktada Sağlık Bakanlığı performansa dayalı ek ödeme sisteminde olduğu gibi kurumsal performans değerlendirmesi ile bireysel performans değerlendirmesi arasında bağlantı kurulmasının stratejik planların başarıyla uygulanmasında önemli olduğu söylenebilir.

Türkiye'de kamu kurumlarında stratejik plan hazırlanması ve performans programları ile faaliyet raporları hazırlanması uygulamaları 5018 sayılı Kamu Mali Yönetimi ve Kontrol Kanununun yürürlüğe girmesiyle başlamıştır. 2007 yılında yayımlanan Kamu İç Kontrol Standartları Tebliği kamu çalışanlarının performanslarının değerlendirilmesi ile ilgili ilk genel yönetsel düzenleme olması açısından dikkat çekicidir. Bununla birlikte halen bütün kamu kurum ve kuruluşlarını bağlayan genel bir bireysel performans değerlendirme düzenlemesi yoktur. Ancak birim hedeflerine göre bireysel hedeflerin belirlendiği çıktı ve sonuç odaklı, aynı zamanda davranışlar ve mesleki bilgi, beceriyi ve yetkinlikleri dikkate alan performans değerlendirme sistemlerinin uygulamaya konmasında fayda vardır.

Kamu görevlilerinin bireysel performanslarının değerlendirilmesi ile ilgili olarak önyarg1 nedeniyle değerlendirmenin tarafsız olamayacağı, stresi ve iş yükünü artıracağı, kurum içi huzurun bozulacağı, çalışanların sosyal hayatını olumsuz etkileyeceği, etik olmayan iş ve işlemlerin artacağı, nitelikten niceliğe yöneliş olacağı, Devlet Memurları Kanununun belirlediği sınıflandırma sisteminin performans değerlendirmesine uygun olmadığ1, toplu ücret artış1 yerine bireysel performansa göre maaş artışına yolacağı, rekabetin yardımlaşmayı azaltacağı, memurluk sisteminin "güvence" ve "kariyer" ilkesinin sözleşmelilik ve performansa dayalı değerlendirme ve ücretlendirme sistemi içinde eriyeceği şeklinde eleştiriler yapılmakla birlikte kamu çalışanlarının bireysel performanslarının değerlendirilmesinin vatandaş memnuniyetini artıracağı, kurumların performanslarının artacağı, motivasyonun sağlanacağı, kurum içi adalet duygusunun meydana geleceği, hizmet kalitesi ve kurumsal bağl1lığını artacağı, iç kontrol sistemi ve yönetişim uygulamalarının olumlu etkileneceği şeklinde destekleyici mahiyette görüşler de ortaya konmaktadır. Eleştirilere rağmen literatürde ve pratikte genel olarak bireysel performans değerlendirme sistemlerinin uygulanabilir ve faydalı olduğu genel kabul görmektedir.

Tabii ki kamu hizmetleri özel hizmetlerden farklıdır. Kamu kurumlarının genel eğilimleri, salt etkinliği sağlamaktan çok, topluma hizmet sunmaktır. Bu nedenle kamu yönetiminde mevcut performans yönetim tekniklerini kullanmakta belirli sınırlılıklar ortaya çıkabilmekle beraber bu kısıtlılıkların hiçbiri performans yönetim sistemlerinin kamu kurumlarında uygulanamayacağı şeklinde yorumlanmamalıdır. Sadece kamu kurum ve kuruluşlarında uygulanacak bireysel performans değerlendirme ve yönetim sistemlerinde, bu kısıtların dikkate alınması ve 657 sayılı Devlet Memurları Kanununda belirlenen sinıflandırma sisteminin bu kapsamda yeniden ele alınması uygun olacaktır.

Kamu kurumlarında, performans yönetim sistemi kurulması, kurum amaç ve hedefleri çerçevesinde birimlerin ve her bir çalışanın bireysel hedeflerinin planlanması ve belirlenmesi, performans değerlendirmesi yapılması ve değerlendirme sonuçlarının ödüllendirme, terfi, takdir, yeniden planlama, stratejik planlama çalışmalarında kullanılması ve bu şekilde kamu çalışanlarının bireysel performansları ile birlikte kurumların ve genel olarak tüm kamu yönetiminin performansının artırılması, sürdürülebilir kalkınmanın sağlanması, ülkeler arası yarışın önem kazandığı küreselleşen dünyada ülkenin gücüne güç katacaktır. Performans değerlendirmesi sonuçlarından faydalanılarak kamu kurumlarının daha kaliteli hizmet ve mal üretmesi, vatandaş memnuniyeti ve hukuksal meşruiyete katkı yapacaktır. Katılımcı yöntemlerle profesyonelce stratejik planlar hazırlanması ve 
bu planların nitelikli kamu görevlileri ile uygulanması, nitelikli çalışanların performanslarının yüksek tutulabilmesi için bireysel performans değerlendirmesi yapılması, kamu yönetiminin etkinliğinin artırılması, küreselleşen, rekabet odaklı dünyada ülkemizin rekabet gücünün artması için etkin bir araç olarak kullanılabilir.

\section{KAYNAKÇA}

Akgemci, T; Güleş H.K. (2010), Işsletmelerde Stratejik Yönetim, Gazi Kitabevi, Ankara.

Aktan, C.C (2006), Kamu Mali Yönetiminde Stratejik Planlama ve Performans Esaslı Bütçeleme, Seçkin Yayınlar1, Ankara.

Akyol, E.M. (2011), Yetkinliğe Dayalı Performans Yönetimi, Nobel Yayın, Ankara.

Aydın, S., Demir M. (2007), Sağlıkta Performans Yönetimi, Performansa Dayalı Ödeme Sistemi, 2. Bask1, Sağlık Bakanlığı Yayını, Ankara.

Barutçugil, İ. (2015), Performans Yönetimi, 3. Baskı, Kariyer Yayıncılık, İstanbul.

Benli, S.; Varol S. (2011), “Mali Sistemde Faaliyet Raporlarının Önemi”, Denetişim Dergisi, 7. Sayı.

Bingöl, D. (2014), Insan Kaynakları Yönetimi, Beta Basım, İstanbul.

Erbaş, M. S. (2015), Kamu Kurumları ve Kalkınma Ajanslarında İç Kontrol Sistemi ve Akreditasyon, Çizgi Yayınevi, Konya.

Ergun, T. (2015), Kamu Yönetimi, Kuram, Siyasa, Uygulama (2. Bask1), TODAİE Yayınları (385 Nolu Yayın), Ankara.

Eroğlu, H. T. (2011), Kamu Yönetiminde Performans, Çizgi Kitabevi, Konya.

Göküş, M.; Karayıldırım, Ş.(2012), "Vatandaşların Belediye Hizmetlerinden Memnuniyeti Karatay Belediyesi Örneği”, Türk İdare Dergisi, Sayı: 474, Haziran Sayısı.

Göze, D. (2008), Kamu Mali Yönetiminde Performansın Yönetilmesi, İç Kontrolün Kurumsal Performansa Etkisi, Yüksek Lisans Tezi, Isparta Süleyman Demirel Üniversitesi, Sosyal Bilimler Enstitüsü, Maliye Ana Bilim Dal1.

Güler, H., Kayral, İ. H., Demir, M, Atasever, M. (2014), "Sağlıkta Yönetici Performans Ölçüm Modeli ve Uygulama Başarısı.” Să̆llkta Performans ve Kalite Dergisi, 8. Sayı.

Kavuzlu, F. (2007), Türk Kamu Yönetiminde Performans Değerlendirme ve Performansa Dayalı Ücret Sistemi, Yüksek Lisans Tezi, Gazi Üniversitesi, Sosyal Bilimler Enstitüsü, Kamu Yönetimi Anabilim Dalı, Yönetim Bilimleri Bilim Dalı, Ankara.

Kayar, N. (2016), Kamu Personel Yönetimi, Ekin Yayınevi, Bursa.

Korkmaz, O. (2011), Örgütsel Performansın Kurumsal Performans Karnesi Yöntemi İle Ölçülmesi: Zonguldak Karaelmas Üniversitesi Hastanesi Üzerine Yürütülen Bir Araştırma, Doktora Tezi, Zonguldak Karaelmas Üniversitesi, İşletme Anabilim Dalı.

Kutlu, Ö. (2012), Karşılaştırmalı Kamu Yönetimi (2. Basım), Çizgi Yayınevi, Konya. 
Nohutçu, A. (2016), Kamu Yönetimi, (12. Bask1), Savaş Yayınevi, Ankara.

Özer, M.A. (2008), 21. Yüzyılda Yönetim ve Yöneticiler, Nobel Yayın, Ankara.

Özkaya, S. (2013), Performans Yönetimi ve Kamu Yönetiminde Performans Yönetimi, Yüksek Lisans Tezi, İstanbul Beykent Üniversitesi, İşletme Anabilimdalı, Yönetim Organizasyon Bilim Dalı.

Saran, U. (2004), Kamu Yönetiminde Yeniden Yapılanma, Atlas Yayınları, Ankara.

Tozlu, A. (2014), Kamu Kesiminde Performans Değerlendirme Sistemi, Kalkınma Bakanlığı Uzmanlık Tezi, Ağustos, Yayın No:2908.

Turhan, M. (2009), Sayıştayın Performans Denetimi Görevi ve Performans Denetimini Uygulama Süreci, Yüksek Lisans Tezi, Gazi Üniversitesi, Sosyal Bilimler Enstitüsü, Kamu Yönetimi Anabilim Dalı, Yönetim Bilimi Bilim Dalı.

Uyargil, C. (2017), Performans Yönetimi Sisteminin Geliştirilmesi, 4. Baskı, Beta Basım, İstanbul.

Yerli, E. (2006), Performans Yönetimi ve Kamu Yönetiminde Performans Yönetimi, Yüksek Lisans Tezi, Selçuk Üniversitesi, Sosyal Bilimler Enstitüsü, Kamu Yönetimi Ana Bilim Dalı.

Yılmaz, T. (2004), Performansa Dayalı Ücret Sistemi: Türkiye'de Uygulanan Performansa Dayalı Ücret Planlarının Kısmi Bir Analizi, Doktora Tezi, Sakarya Üniversitesi, Sosyal Bilimler Enstitüsü, Çalışma Ekonomisi ve Endüstri İlişkileri Ana Bilim Dalı.

Y1lmazgil, S.M. (2012), Türk Kamu Yönetiminde Performans Değerlendirmenin Kamu Çalışanlarının İş Stresine Etkisi, Yüksek Lisans Tezi, Selçuk Üniversitesi, Sosyal Bilimler Enstitüsü, Kamu Yönetimi Ana Bilim Dalı.

\section{HUKUKİ KAYNAKLAR}

Cumhurbaşkanlığı Teşkilatı Hakkında Cumhurbaşkanlığı Kararnamesi (1 nolu), T.C. Resmi Gazete, 30474 say11, 10 Temmuz 2018.

Devlet Memurları Kanunu (657 say111),

(1965), T.C. Resmi Gazete, 12056 say1l1, 23 Temmuz 1965

Kamu İdarelerince Hazırlanacak Faaliyet Raporları Hakkında Yönetmelik, (2006), T.C. Resmi Gazete, 26111 say1l, 17 Mart 2006.

Kamu İdarelerince Hazırlanacak Performans Programları Hakkında Yönetmelik, (2008), T.C. Resmi Gazete, 26927 say1l, 05 Temmuz 2008.

Kamu İdarelerinde Stratejik Planlamaya İlişkin Usul ve Esaslar Hakkında Yönetmelik, (2018), T.C. Resmi Gazete, 30344 sayıl1, 26 Şubat 2018.

Kamu İdareleri İçin Stratejik Planlama Kılavuzu, http://www.sp.gov.tr/tr/html/18/Kilavuz+ve+Rehberler/; (9 Ocak 2021).

Kamu Mali Yönetim ve Kontrol Kanunu, 5018 sayılı, (2003). T.C. Resmi Gazete, 25326 sayıl1, 24 Aralık 2003. 
Kamuda İnsan Kaynakları Yönetimi Çalışma Raporu, Kalkınma Bakanlığı (2018), https://sbb.gov.tr/wpcontent/uploads/2020/04/KamudaInsanKaynaklariCalismaGrubuRaporu.pdf;

(9 Ocak 2021)

Kalkınma Planı (10. 2014-2018 Arası), http://www.kalkinma.gov.tr/Lists/Kalknma\%20Planlar/Attachments/12/Onuncu\%20Kalkınma\%20Plan 1.pdf, (9 Ocak 2021).

Kalkınma Planı (11), (2019-2023 Arası), file://C:/Users/ASUS/Desktop/ON_BIRINCI_KALKINMAPLANI_2019-2023.pdf; (04 Ocak 2021).

Kamu Personelinin Başarılarının Değerlendirilmesine İlişkin Genel Yönetmelik Taslağ1, https://www.memurlar.net/common/news/documents/593903/basari-degerlendirme-taslak.pdf; (9 Ocak 2021).

Kamu İç Kontrol Standartları Tebliği, (2007), T.C. Resmi Gazete, 26738 sayılı, 26 Aralık 2007.

Orta Vadeli Program (2018-2010), http://www.kalkinma.gov.tr/Lists/Yaynlar/Attachments/783/Orta\%20Vadeli\%20Program\%2020182020.pdf, (1 Şubat 2019). 